\title{
SISTEM PENGAMBIL KEPUTUSAN PEMILIHAN SMARTPHONE ANDROID DENGAN KAMERA SELFIE TERBAIK
}

\author{
Indarti \\ Program Studi Sistem Informasi \\ STMIK Nusa Mandiri Sukabumi/ \\ e-mail: indarti.ini@nusamandiri.ac.id
}

\begin{abstract}
Smartphone saat ini merupakan kebutuhan setiap masyarakat. Hal ini terlihat dari semua kalangan menggunakannya terutama untuk kebutuhan hiburan dalam hal ini adalah berselfie. Karena hal itu banyak vendor-vendor merek smartphone android yang menciptakan smartphone dengan spesifikasi yang tinggi, karena banyaknya pilihan smartphone android selfie yang beredar di pasaran. Salah satu cara mengatasi masalah tersebut adalah dengan adanya suatu metode yang dapat memberikan rekomendasi sebagai bahan pertimbangan untuk pengambilan keputusan secara tepat. Penelitian ini bertujuan membuat sistem pendukung keputusan pemilihan smartphone android selfie dengan menerapkan metode Analytical Hierarchy Process yang dapat menyelesaikan masalah dengan cara membandingkan antara smartphone android selfie satu dengan yang lain. Adapun yang menjadi kriteria dalam pertimbangan pemilihan smartphone android selfie yaitu harga, jenis layar, kualitas kamera, kapasitas memori, baterai. Hasil dari penelitian ini berupa kesimpulan perhitungan data dari kuesioner yang disebar kepada mahasiswi dalam memilih smartphone android selfie yang dapat dijadikan bahan pertimbangan untuk pengambilan keputusan dalam memilih smartphone android selfie yang paling banyak dipilih mahasiswi dengan menerapkan metode Analytical Hierarchy Process sehingga diperoleh hasil yang terbaik dalam pengambilan keputusan.
\end{abstract}

Kata Kunci : Smartphone, Selfie, AHP

\section{PENDAHULUAN}

Smartphone Android dengan kamera selfie terbaik yang ada di era ini membuat smartphone jenis ini menarik perhatian orang banyak terutama mahasiswi, karena semakin maraknya kegiatan berselfie pada era sekarang ini membuat vendor- vendor menciptakan smartphone dengan kualitas kamera yang semakin bagus dan harga yang bersahabat. Jenis Smartphone Android dengan kamera selfie yang saat ini diminati oleh para mahasiswa yaitu, Oppo f1s, Lenovo Vibe S1, Sony Xperia C5 dan Vivo V5 Plus. Maka peneliti melakukan pengujian bagi keempat kamera tersebut untuk mendapatkan hasil yang paling diminati, layak dan dengan harga terjangkau oleh para mahasiswi, dengan menggunakan metode Analytical Hierarchy Process (AHP).

Ponsel cerdas (smartphone) adalah telepon genggam yang mempunya kemampuan dengan penggunaan dan fungsi yang menyerupai komputer.
Menurut (A. Satyaputra; E. M. Aritonang, 2010) Aplikasi mobile adalah sebuah aplikasi yang memungkinkan untuk melakukan mobilitas dengan menggunakan perlengkapan seperti PDA, telepon seluler atau handphone.

Menurut (Arifianto Teguh, 2011)“Android merupakan perangkat bergerak pada sistem operasi untuk telepon seluler yang berbasis linux.

Menurut (Masirul, 2015) Selfie adalah jenis foto potret diri yang diambil oleh diri sendiri dengan menggunakan sebuah kamera, baik kamera digital atau kamera telepon.

Menurut (Abriyanto Arif, 2016), Microsoft office bisa dijalankan pada berbagai sistem operasi, seperti Microsoft Windows pastinya dan Maccintosh atau Mac $O S$.

Menurut (Tehubijuluw, 2014)“dikatakan sebuah penelitian ilmiah adalah sebuah usaha untuk menemukan, mengembangkan, dan menguji kebenaran suatu pengetahuan dengan menggunakan metode ilmiah tertentu".

Menurut (Kusrini, 2007) "sistem merupakan kumpulan elemen yang saling berkaitan yang bertanggung jawab memproses masukan (input) sehingga menghasilkan keluaran (Output)".

Menurut (Sugiyono, 2005) menyatakan bahwa metode deskriptif adalah suatu metode yang digunakan untuk menggambarkan atau menganalisis suatu hasil penelitian tetapi tidak digunakan untuk membuat kesimpulan yang lebih luas.

Menurut (Kusrini, 2007) "Keputusan merupakan kegiatan memilih suatu strategi atau tindakan dalam pemecahan masalah tersebut".

Menurut (Kusrini, 2007)," Decision Support System (DSS) merupakan sistem informasi interaktif yang menyediakan informasi, pemodelan, dan pemanipulasian data".

Menurut (Turban, E, dkk, 2005) dalam(Kusrini, 2007), tujuan dari DSS adalah :

1. Membantu manajer dalam pengambilan keputusan atas masalah semi-terstruktur.

2. Memberikan dukungan atas pertimbangan manajer dan bukannya dimaksudkan untuk menggantikan fungsi manajer.

3. Meningkatkan efektivitas keputusan yang diambil manajer lebih daripada perbaikan efisiensinya.

4. Kecepatan komputasi.

5. Peningkatan produktivitas. 
6. Dukungan kualitas.

7. Berdaya saing.

8. Mengatasi keterbatasan kognitif dalam pemrosesan dan penyimpanan.

\section{METODOLOGI PENELITIAN}

Penelitian yang digunakan oleh peneliti menggunakan metode Analytical Hierarchy Process (AHP) dan metode deskriptif yang dapat diartikan sebagai prosedur pemecahan masalah yang diselidiki dengan menggambarkan keadaan subjek atau objek dalam penelitian yang berupa orang, lembaga, masyarakat dan yang lainnya yang ada pada saat sekarang berdasarkan fakta-fakta yang tampak atau apa adanya.

\section{a. Tahapan Penelitian}

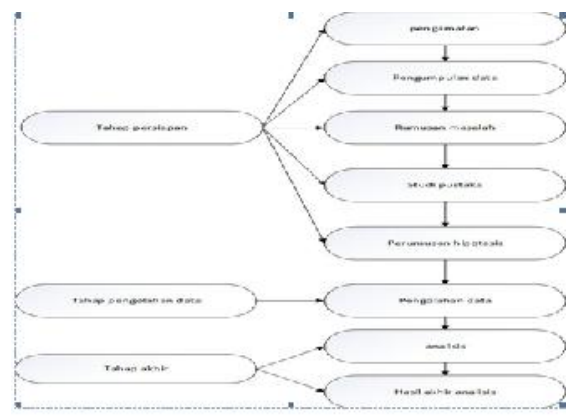

Gambar 1.

Langkah-Langkah Penelitian

Adapun tahapan penelitian yang dilakukan adalah sebagai berikut :

\section{Pengamatan}

Langkah pertama penulis melakukan pengamatan secara langsung kepada mahasiswi yang sedang berfoto selfie dengan menggunakan Smartphone Android di beberapa kampus.

2. Pengumpulan Data

Pengumpulan data yang dilakukan penulis menggunakan angket atau kuesioner, yang diambil dari pendapat mahasiswi yang sedang berfoto selfie dan jenis smartphone yang digunakan.

3. Perumusan Masalah

a. Bagaimana cara menentukan pemilihan jenis Smartphone Android Selfie dengan menggunakan metode Analytical Hierarchy Process?

b. Smarthphone android selfie manakah yang diminati oleh mahasiswi untuk berselfie?

c. Bagaimana merancang Sistem Penunjang Keputusan dalam pemilihan smartphone android selfie yang sesuai dengan keinginan mahasiswi? d. Kriteria apa saja yang ditetapkan dalam Sistem Pendukung Keputusan Pemilihan Smartphone Android Selfie?

4. Studi Pustaka

Studi pustaka yang digunakan penulis diambil dari jurnal-jurnal, buku-buku yang mengenai metode AHP, metode deskriptif dan pengolahan datanya.

5. Perumusan Hipotesis

Perumusan hipotesis dilakukan dengan menggunakan teori-teori yang ada dengan data-data yang telah dikumpulkan. Selanjutnya, perumusan hipotesis dilakukan dengan membuat pernyataanpernyataan yang akan diuji secara statistik untuk memberikan jawaban sementara terhadap permasalahan penelitian yang dilakukan.

6. Pengolahan data

Penulis mengumpulkan data yang diambil dari penyebaran kuesioner kepada mahasiswi di beberapa kampus sebanyak 100 responden.

7. Analisis

Setelah itu penulis menganalisis data yang telah dikumpulkan untuk mendapatkan hasil hipotesis yang akan diuji sesuai dengan teori yang ada.

8. Hasil Akhir Analisis

Penulis melakukan penarikan kesimpulan berdasarkan dari data-data yang telah dianalisa sebelumnya sehingga mendapatkan hasil berupa gambaran keseluruhan dari hasil penelitian smartphone android selfie.

\section{b. Instrumen Penelitian}

Instrumen penelitian yang digunakan adalah dengan penyebaran kuesioner. Pada penelitian ini penulis menggunakan kuesioner jenis pertanyaan berskala (Scaled-Response Questions). Kuesioner tersebut terdiri dari 9 (sembilan) lembar yang di dalamnya berisi 6 (pertanyaan) dengan 40 butir pilihan untuk memilih 5 (lima) kriteria yang paling berpengaruh terhadap pemilihan smartphone android selfie di antaranya ada harga, jenis layar, kapasitas memori, kualitas kamera, daya tahan baterai, serta untuk memilih 4 (empat) alternatif smartphone android selfie yang terdiri dari Oppo F1s, Lenovo Vibe S1, Sony Xperia C5, dan Samsung GalaxyJ7 Prime.

Tabel 1.

Skala Penilaian Perbandingan Pasangan 


\begin{tabular}{|c|c|}
\hline Intcrsitas Kcpentingan & Kctcrangan \\
\hline 1 & Keflua elemen sama penlingnya \\
\hline 3 & $\begin{array}{l}\text { T. - mon yang satu sedikit letih penting daripada } \\
\text { lemen vang lainnva }\end{array}$ \\
\hline 5 & $\begin{array}{l}\text { Llenen yang satu lebih penting daizeada slemen } \\
\text { tainnyo }\end{array}$ \\
\hline 7 & $\begin{array}{l}\text { Salu elemen ielas lelih wullak penting datipatis } \\
\text { dcmon lainnxa }\end{array}$ \\
\hline 9 & $\begin{array}{l}\text { Satu elemen mutlak pentins daripada elemen } \\
\text { lainnya. }\end{array}$ \\
\hline 7.4 .6 .8 & $\begin{array}{l}\text { Nilai nilai antura dua nilai pertimbangan yang } \\
\text { berdekatan }\end{array}$ \\
\hline Kebalikan & 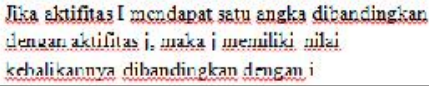 \\
\hline
\end{tabular}

Sumber : Kusrini (2007:134)

Tabel 2.

Pemilihan Kriteria

\begin{tabular}{|c|c|c|}
\hline \multicolumn{2}{|c|}{$\begin{array}{l}\text { Dalam Pemilihan Smartphone Android } \\
\text { Selfie, manakah yang lebih penting dari } \\
\text { kriteria-kriteria berikut ini? }\end{array}$} & \multirow{2}{*}{$\begin{array}{l}\text { Berapa tingkat Kepentingannya } \\
\text { ? } \\
\text { (1) (2) (3) (4) (5) (7) (8) }\end{array}$} \\
\hline Harga & Jenis Layar & \\
\hline Harga & Memori & (1) (2) (3) (4) (5) (6) 7 (8) (9) \\
\hline Harga & Kamera & (1) (2) (3)(4)(5)(7)(9) \\
\hline Harga & Baterai & (1) (2) (3) (4) (5)(7)(7) (9) \\
\hline Jenis Layar & Memori & (1) (2) (3) (4) (5)(6)(7) (9) \\
\hline Jenis Layar & Kamera & (1) (2) (3) (4) (5) (6) (7) 8 (9) \\
\hline Jenis Layar & Baterai & (1) (2) (3) (4) (5) 6) (7) 8) \\
\hline Memori & Kamera & (1) (2) (3) (4) (5) (6)(7) (9) \\
\hline Memori & Baterai & (1) (2) (3) (4) (5) (6) 7 (8) (9) \\
\hline Kamera & Baterai & (1) (2) (3) (4) (5) (6) 7 (8) (9) \\
\hline
\end{tabular}

Sumber : Pengolahan Data

c. Metode Pengumpulan Data, Populasi dan Sampel Penelitian

\section{Pengumpulan Data}

Pengumpulan data dan informasi yang dilakukan langsung ke responden dengan cara wawancara dan penyebaran kuesioner. Kuesioner tersebut disebarkan kepada 100 (seratus) mahasiswi dengan berbagai macam program studi di beberapa kampus, setelah itu hasil kuesioner akan diolah menggunakan microsoft excel dan dicocokan dengan expert choice agar hasil lebih akurat, dari sini akan didapat analisa terhadap tingkat pengaruh yang dihasilkan dari pencarian data. Sementara untuk wawancara digunakan open ended question dan wawancara akan bersifat semi-structured. Maksudnya bahwa jawaban responden tidak ditentukan, dalam arti bisa beraneka ragam, tidak dibatasi

\section{Populasi}

Populasi yang dijadikan sampel dalam penelitian ini adalah 100 (seratus) mahasiswi di beberapa kampus yang terdiri dari wanita disegala usia, program studi serta tingkatan untuk mewakili populasi keseluruhan.

\section{Sampel Penelitian}

Pengambilan sampel dalam penelitian ini menggunakan teknik atau metode sample random samping. Sampel dipilih dari elemen populasi secara acak, dimana populasi mempunyai hak yang sama untuk dijadikan sampel. Pada penelitian ini jumlah populasi tidak diketahui sehingga sampel yang diambil sebanyak 100 (seratus) responden agar mewakili populasi secara keseluruhan. Populasi yang diambil adalah mahasiswi di beberapa kampus dengan berbagai macam tingkatan usia, tingkatan serta jurusan yang diambil.

Metode penarikan sampel acak sederhana merupakan suatu prosedur yang memungkinkan setiap elemen dalam populasi akan memiliki peluang yang sama untuk dijadikan sampel.

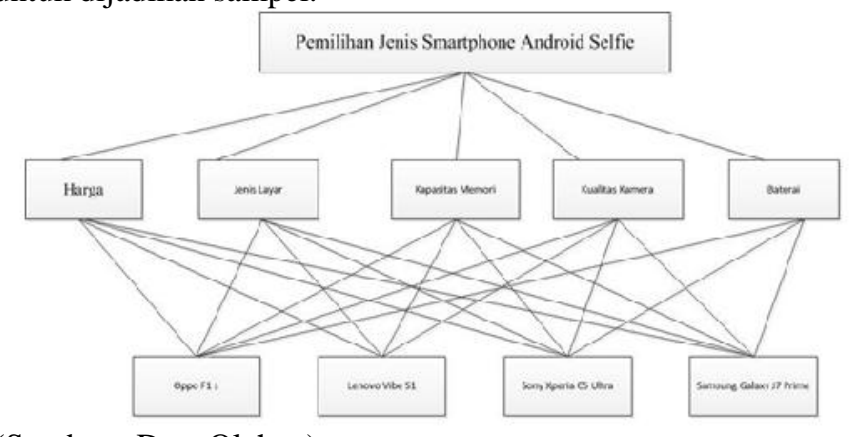

(Sumber : Data Olahan)

Gambar 2.

Hirarki Pemilihan Smartphone Android Selfie

\section{d. Pengolahan Data}

Tabel 3.

Perbandingan Berpasangan Kriteria Utama

Sumber data : Data Olahan (2017)

Tabel 4.

\begin{tabular}{|l|c|c|c|c|c|}
\hline \multicolumn{1}{|c|}{ Kriteria } & harga & jenis layar & $\begin{array}{c}\text { kapasitas } \\
\text { memori }\end{array}$ & $\begin{array}{c}\text { Kualitas } \\
\text { kamera }\end{array}$ & Baterai \\
\hline Harga & 1 & 0,5 & 0,33 & 0,25 & 0,33 \\
\hline jeriis layar & 2 & 1 & 0,5 & 0,33 & 0,5 \\
\hline kapasitas memori & 3 & 2 & 1 & 0,5 & 1 \\
\hline kualitas kamera & 4 & 3 & 2 & 1 & 2 \\
\hline Baterai & 3 & 2 & 1 & 0,5 & 1 \\
\hline \multicolumn{1}{|c|}{ Total } & 13 & 8,5 & 4,83 & 2,58 & 4,83 \\
\hline
\end{tabular}

Matriks Faktor Pembobotan Hirarki Kriteria Utama Yang Dinormalkan

\begin{tabular}{|l|l|l|l|l|l|l|ll|}
\hline Kriteria & harga & $\begin{array}{l}\text { jenis } \\
\text { layar }\end{array}$ & $\begin{array}{l}\text { kapasitas } \\
\text { memori }\end{array}$ & $\begin{array}{l}\text { kualitas } \\
\text { kamera }\end{array}$ & baterai & jumlah & Matriks & $\begin{array}{l}\text { Nilai } \\
\text { Eigen }\end{array}$ \\
\hline Harga & 0,333 & 0,059 & 0,068 & 0,097 & 0,068 & 0,626 & 5 & 0,119 \\
\hline jenis layar & 0,151 & 0,118 & 0,104 & 0,128 & 0,101 & 0,606 & 5 & 0,115 \\
\hline $\begin{array}{l}\text { karasitas } \\
\text { memori }\end{array}$ & 0,231 & 0,235 & 0,207 & 0,194 & 0,207 & 1,074 & 5 & 0,204 \\
\hline $\begin{array}{l}\text { kualilas } \\
\text { kamera }\end{array}$ & 0,308 & 0,353 & 0,414 & 0,388 & 0,414 & 1,876 & 5 & 0,357 \\
\hline baterai & 0,231 & 0,235 & 0,207 & 0,194 & 0,207 & 1,074 & 5 & 0,204 \\
\hline total & 1 & 1 & 1 & 1 & 1 & 5 & & \\
\hline
\end{tabular}

Sumber Data : Data olahan (2017)

Selanjutnya nilai vector eigen dikalikan dengan matriks semula, menghasilkan nilai untuk tiap baris, yang 
selanjutnya setiap nilai dibagi kembali dengan nilai vector yang bersangkutan.

Nilai rata-rata dari hasil pembagian ini merupakan principal eigen value maksimum ( $\lambda \max )$.

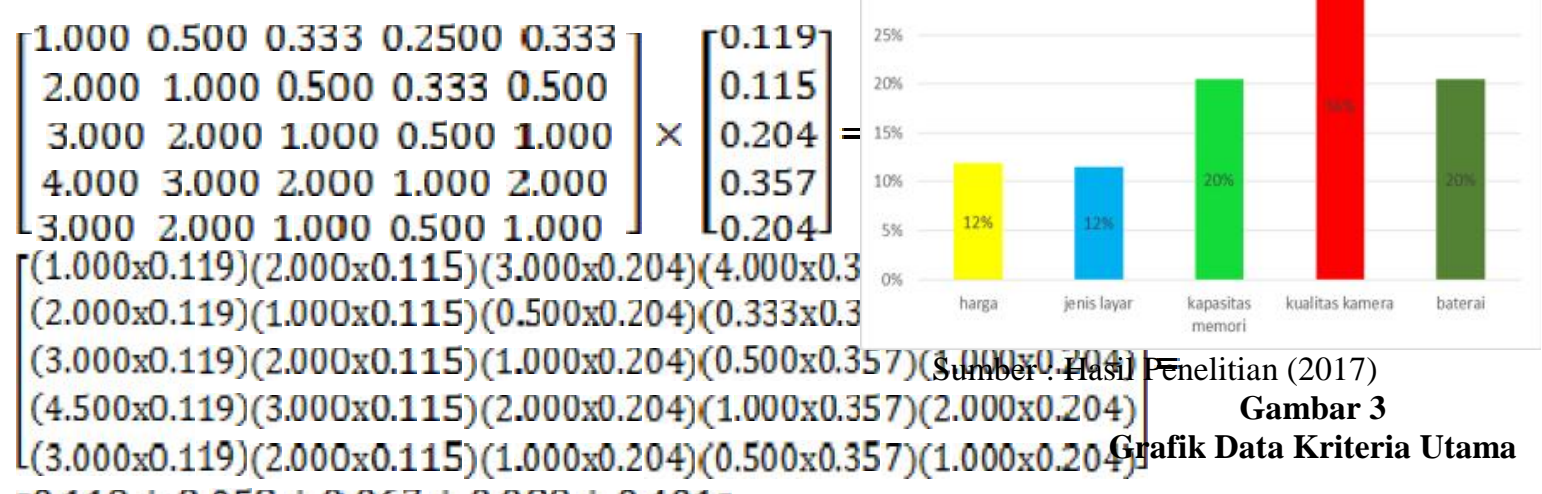

$[0.119+0.058+0.067+0.089+0.401]$

$0.238+0.115+0.102+0.118+0.676$

$0.357+0.231+0.204+0.178+0.175=$

$0.476+0.346+0.409+0.357+0.996$

$[0.357+0.231+0.204+0.178+0.175]$

$\left[\begin{array}{l}0.401 \\ 0.676 \\ 1.175 \\ 1.996 \\ 1.175\end{array}\right]+\left[\begin{array}{l}0.099 \\ 0.061 \\ 0.235 \\ 0.061 \\ 0.155\end{array}\right]=\left[\begin{array}{l}1739 \\ 5.855 \\ 5.751 \\ 5.593 \\ 5.751\end{array}\right]$

$$
\lambda \max =\frac{24.689}{5}=4.938
$$

Karena matriks berordo 5 (yakni terdiri dari 5 kriteria), nilai indeks konsistensi (CI) yang diperoleh :

$$
C l=\frac{\left(\lambda \max x^{-\mathrm{n})}\right.}{(n-1)}=\frac{(4.938-5)}{(5-1)}=\frac{-0.319}{4}=0.080
$$

Untuk n=5, RI=1,120 tabel (Saaty, Thomas L, and Luis G. Vargas, 1994). Maka :

$$
C R=\frac{C I}{R I}+\frac{-0.080}{1.120}=-0.071
$$

Karena $\mathrm{CR}<0,100$ maka preferensi responden adalah konsisten.Dari Hasil perhitungan pada tabel diatas menunjukkan bahwa Kualitas Kamera merupakan kriteria yang paling penting bagi pemilihan jenis smartphone android selfie dengan nilai bobot 0.357 atau $36 \%$ berikutnya adalah harga dengan nilai bobot 0.119 atau $12 \%$ kemudian Jenis Layar dengan nilai bobot 0.115 atau $12 \%$ kemudian Kapasitas memori dengan nilai bobot 0.204 atau $20 \%$ dan terakhir adalah Baterai dengan nilai bobot 0.204 atau $20 \%$.

\section{A. Pengambilan Keputusan}

Untuk mencari kesimpulan akhir dari masingmasing alternatif pemilihan smartphone android selfie yaitu dengan cara nilai eigen masing-masing alternatif dikalikan dengan nilai eigen kriteria utama.

Tabel 5.

Nilai Eigen Alternatif

\begin{tabular}{|l|c|c|c|c|c|}
\hline & Harga & $\begin{array}{c}\text { jenis } \\
\text { layar }\end{array}$ & $\begin{array}{c}\text { Kapasitas } \\
\text { memor }\end{array}$ & $\begin{array}{c}\text { Kapasitas } \\
\text { kamera }\end{array}$ & Batcrai \\
\hline Oppo F1S & 0,227 & 0,484 & 0,558 & 0,513 & 0,490 \\
\hline Lcnovo VibcS1 & 0,122 & 0,297 & 0,112 & 0,166 & 0,306 \\
\hline Sury Xperia C5 U11ra & 0,227 & 0,109 & 0,071 & 0,160 & 0,079 \\
\hline $\begin{array}{l}\text { Samsung Galaxy J5 } \\
\text { Prmc }\end{array}$ & 0,423 & 0,109 & 0,259 & 0,160 & 0,126 \\
\hline
\end{tabular}

Sumber Data : Data olahan

Tabel 6.

Nilai Eigen Kriteria Utama

\begin{tabular}{|c|c|}
\hline Harga & 0,119 \\
\hline jenis layar & 0,115 \\
\hline kapsitas memori & 0,204 \\
\hline kapasitas kamera & 0,357 \\
\hline Baterai & 0,204 \\
\hline
\end{tabular}

Sumber Data : Data olahan 


$\begin{aligned} \text { Pppo F1s } & (0,227 \times 0,119)+(0,484 \times 0,0115)+(0,558 \times 0,204)+(0,513 \times 0,357)+ \\ & (0,490 \times 0,204) \\ = & 0,027+0,056+0,114+0,183+0,100 \\ = & 0,480 \\ = & (0,122 \times 0,119)+(0,297 \times 0,115)+(0,112 \times 0,204)+(0,166 \times 0,357)+1 . \\ & (0,306 \times 0,204) \\ = & 0,015+0,034+0,023+0,059+0,062 \\ = & 0,: 93 \\ = & (0,227 \times 0,115)+(0,109 \times 0,115)+(0,071 \times 0,204)+(0,160 \times 0,357)+2 . \\ & (0,079 \times 0,204) \\ = & 0,027+0,013+0,014+0,057+0,016 \\ = & 0,27 \\ \text { Sony Xperia C5 Ultra Vibe S1 } & (0,432 \times 0,119)+(0,109 \times 0,115)+(0,259 \times 0,204)+(0,160 \times 0,357)+ \\ & (0,126 \times 0,204) \\ = & 0,050+0,013+0,053+0,057+0,026 \\ = & 0,: 99\end{aligned}$

Berdasarkan Vector Eigen keputusan terlihat bahwa bobot prioritas tertinggi yaitu Oppo F1s dengan nilai 0,480 atau $48 \%$. Maka dapat disimpulkan bahwa mahasiswi condong memilih Oppo F1s sebagai Smartphone Android Dengan Kamera Selfie Terbaik dari segi harga, jenis layar, kapasitas memori, kualitas kamera, dan baterai. Disusul dengan Samsung Galxy J5 Prime dengan nilai 0,199 atau 20\%, lalu Lenovo Vibe S1 dengan nilai 0,193 atau 19\%, serta yang terbawah adalah Sony Xperia C5 Ultra dengan nilai 0,127 atau $13 \%$.

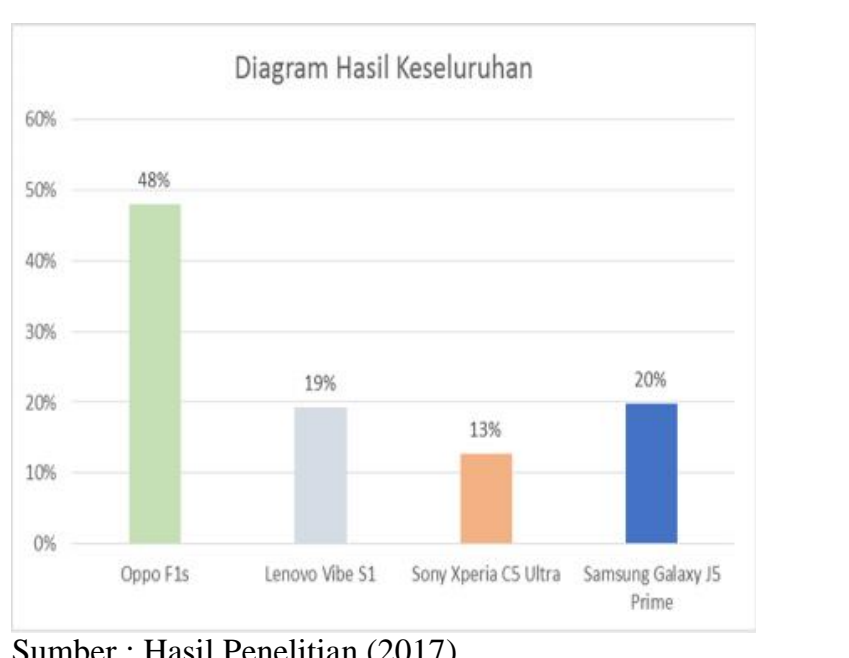

Sumber : Hasil Penelitian (2017)

Gambar 4.

Grafik Data Perhitungan Hasil

$\mathrm{HH}_{0}$ : Tidak terdapat pengaruh positif spesifikasi dalam menentukan Smartphone Android self

Ha : Terdapat pengaruh positif spesifikasi dalam menentukan Smartphone Android selfie

\section{KESIMPULAN}

Penulis membuat kesimpulan dari hasil pengolahan data yang menggunakan metode AHP dan metode Deskriptif, yaitu:

Sistem pengambilan keputusan yang melibatkan banyak kriteria alternatif pilihan, metode AHP sangat cocok digunakan karena metode ini memperlihatkan perbandingan antara kriteria yang satu dengan yang lainnya.

2. Pemilihan Smartphone Android Selfie dengan menggunakan metode AHP yang paling diminati untuk berfoto selfie oleh mahasiswi adalah jenis smartphone Oppo F1s dengan nilai 0,480 atau 48\%.

3. Metode AHP memudahkan dalam pengambilan keputusan suatu produk atau jasa berdasarkan kriteria dan alternatif yang disusun menjadi suatu hirarki.

4. Metode deskriptif dapat memudahkan bagi para peneliti dalam tahap menganalisa sebuah permasalahan yang akan di teliti.

5. Kriteria yang digunakan dalam pemilihan jenis Smartphone Android Selfie yaitu harga, jenis layar, kapasitas memori, kualitas kamera dan baterai.

\section{DAFTAR PUSTAKA}

A. Satyaputra; E. M. Aritonang. (2010). Java for Beginners with Eclipse Juno. Jakarta: Elexmedia Komputindo.

Abriyanto Arif. (2016). http://arifabriyanto.mhs.narotama.ac.id/2016/01/18/ pengertian-dan-sejarah-microsoft-excel.

Arifianto Teguh. (2011). Menurut Teguh Arifianto. Menurut Teguh Arifianto: Menurut Teguh Arifianto.

Kusrini. (2007). Konsep dan Aplikasi Sistem Pendukung Keputusan. Yogyakarta: ANDI OFFSET.

Masirul. (2015). http://masirul.com/pengertian-selfiesejarah-selfie/ Posted on 25 July. (2016).

Sugiyono. (2005). Memahami Penelitian Kualitatif. Bandung: ALFABET.

Tehubijuluw, F. (2014). Metodologi Penelitian, Cara Mudah Membuat Makalah, Skripsi, Tesis, dan Disertasi. Tangerang: PT. Matana Bina Utama.

Turban, E, dkk. (2005). Decision Support Systems and Intelligent Systems. Edisi 7 Jilid 1. Andi Yogyakarta.

\section{PROFIL PENULIS}

Indarti. Jakarta 10 September 1983. Lulus tahun 2008 di STMIK Swadharma Jakarta Jurusan Sistem Informasi. Lulus tahun 2011 di Pascasarjana STMIK Nusa Mandiri Jakarta Program) Program Studi Magister Ilmu Komputer. Aktif mengikuti seminar dan menulis paper di beberapa jurnal diantara Cakrawala, Pilar. Dan pernah mengikuti Seminar Internasional. 